\begin{tabular}{c|c|c|c|c|} 
DOI: http://dx.doi.org/10.21276/ap.covid19.2021.10.1.6 \\
Annals of Phytomedicine: An International Journal \\
http://www.ukaazpublications.com/publications/index.php \\
Print ISSN : 2278-9839 Online ISSN : 2393-9885
\end{tabular}

\title{
Ameliorative potential of phytochemicals against side effects of COVID-19 drugs: A review
}

\author{
Priti D. Vihol, Rasesh D. Varia, Ratn Deep Singh*, Jatin H. Patel, Harshad B. Patel**, Sarita Devi* and Urvesh D. Patel* \\ College of Veterinary Science and A.H., Navsari, Kamdhenu University, Navsari-396450, Gujarat, India \\ *College of Veterinary Science and A.H., S.K. Nagar, Kamdhenu University, S.K. Nagar-385506, Gujarat, India \\ **College of Veterinary Science and A.H., Junagadh, Kamdhenu University, Junagadh-362001, Gujarat, India
}

\begin{tabular}{|c|c|}
\hline Article Info & Abstract \\
\hline $\begin{array}{l}\text { Article history } \\
\text { Received } 1 \text { April } 2021 \\
\text { Revised } 17 \text { May } 2021 \\
\text { Accepted } 18 \text { May } 2021 \\
\text { Published Online } 30 \text { June } 2021\end{array}$ & $\begin{array}{l}\text { The pandemic of coronavirus disease-19 (COVID-19) remains to nag human race with its more infectious } \\
\text { second wave in most of highly populated countries including India. Till date, no specific antiviral drug } \\
\text { is discovered or developed which is cent-per-cent effective against severe acute respiratory syndrome } \\
\text { coronavirus-2 (SARS-CoV-2), the causative agent of COVID-19. The efficacy of developed vaccines are } \\
\text { said to reduce severity of disease, but the mutation led to origin of more infectious variants. In such }\end{array}$ \\
\hline $\begin{array}{l}\text { Keywords } \\
\text { Drugs } \\
\text { COVID-19 } \\
\text { Side effects } \\
\text { Phytochemicals } \\
\text { Ameliorating effect }\end{array}$ & $\begin{array}{l}\text { scenario, medical management of COVID-19 largely depends upon repurposed drugs like azithromycin, } \\
\text { remdesivir, chloroquine, hydroxychloroquine and tocilizumab. However, none of these repurposed } \\
\text { drugs is devoid of side effects or drug-induced toxicities which may be fatal too sometimes. Scientific } \\
\text { research literature on phytochemicals hints that these miracle phytomolecules may not only be useful } \\
\text { in direct therapeutic effect but also have potential to reduce or ameliorate the side-effects of current } \\
\text { repurposed drugs used in treatment of COVID-19. This review critically elaborates the side-effects of } \\
\text { COVID-19 drugs and the six potential phytochemicals, viz., quercetin, baicalein, kaempferol, curcumin, } \\
\text { catechins and gingerols which have potentials to ameliorate such side-effects. The very purpose of the } \\
\text { review paper is to promote the scientific studies on these phytomolecules in the management of } \\
\text { COVID-19, as there are predictions that human kind has to learn to live with this disease. }\end{array}$ \\
\hline
\end{tabular}

\section{Introduction}

Coronavirus disease-19 (COVID-19) spread is the pandemic condition, caused by the severe acute respiratory syndrome coronavirus-2 (SARS-CoV-2). World health organization had confirmed cases of the disease in December, 2019 and declared it as pandemic in 2020 (WHO, 2020). Since the outbreak of the COVID-19, more than 1 million people have lost their lives due to the pandemic, and the global economy is expected to contract by a staggering nearly about 4.3 per cent in 2020 (UN, 2020). Till date, no treatment has shown 100 per cent efficacy against this disease due to wide range of symptoms and sequelae. Researchers and clinicians are trying various therapeutic regimens for this disease by applying their experience and the knowledge. Certain herbal medicines containing active phytochemicals reported to possess antimicrobial, antiviral, antiinflammatory and immunostimulant properties. The immunomodulatory effect of the drug is believed to be beneficial against COVID19 (Nugraha et al., 2020). However, multiple drug usage to manage COVID-19 and the chances of drug-drug interaction with more complicated side may be possible especially in old age and comorbid patients.

Corresponding author: Dr. Urveshkumar D. Patel Associate Professor, Department of Veterinary Pharmacology and Toxicology, College of Veterinary Science and A.H., Junagadh, Kamdhenu University, Junagadh-362001, Gujarat, India E-mail: urvesh1981@yahoo.com

Tel.: +91-9725003818

Copyright (c) 2021 Ukaaz Publications. All rights reserved.

Email: ukaaz@yahoo.com; Website: www.ukaazpublications.com
Therapeutic management of COVID-19 includes infection prevention, use of efficacious drugs, supportive care particularly oxygen supply with mechanical ventilator as and when needed. The FDA has approved the drug, remdesivir, for the treatment of COVID-19 positive patients. Favipiravir was first used against SARS-CoV-2 in Wuhan. In June 2020, favipiravir received the DCGI approval in India for mild and moderate COVID-19 infections (Agrawal et al., 2020). Till date, various drugs have been tested and approved to be use in emergency for the treatment of patients having COVID-19, particularly to save the life of the severely affected patients.

Azithromycin exhibited a synergistic antiviral effect towards SARSCOV-2, whilst mixed with hydroxychloroquine both in vitro and in a clinical setting (Andreani et al., 2020; Gautret et al., 2020). Azithromycin up-regulates the production of type I and III interferons (specifically interferon- $\beta$ and interferon- $\lambda$ ), and genes involve in virus reputation including MDA5 and RIG-I (Schögler et al., 2015; Menzel et al., 2016; Li et al., 2019). Azithromycin regulates and/or decreases the production of IL-1 $\beta$, IL-6, IL-8, IL-10, IL-12, and IFN- $\alpha$ (Zarogoulidis et al., 2012; Cai et al., 2013). Hydroxychloroquine also has immunomodulatory effects, and has been reported to decrease various ILs, IFN- $\alpha$, and tumor necrosis factor (Silva et al., 2013). Azithromycin and Hydroxychloroquine, both decrease the production of major inflammatory cytokines such as IL-1 and IL-6. These mechanisms are universally concerned inside the innate response towards infectious agents, and probably towards SARSCoV-2. During the therapeutic use of drugs in COVID-19 patient, many side effects and adverse events may be encountered which lead to complications in severely affected patients who may have 
compromised function of vital organs. Thus, the side effects of the drugs, which are used in COVID-19 patients, should be minimized through use of combination of drugs with proper therapeutic drug monitoring and use of various phytochemicals or plant based remedies. There are various reports of efficacy of phytomedicine with ameliorating effect against drug or toxicant-induced side effects. We believe that simultaneous treatment with phytochemicals may have important role to minimize the side effects of COVID-19 drugs. However, such drug-drug interaction studies should be done before use of such combination or consultation of physician is must to avoid possible drug-drug interactions.

Key focus of this review is to highlight the significant information about mechanism of action, side effects and interaction of drugs which are being used for COVID-19 as well as ameliorating potential of few key phytochemicals against side-effects caused by common COVID-19 drugs. This review would further be helpful the scientific community involved in designing efficacious and safe therapeutic regimen for the treatment of COVID-19.

\section{COVID-19 drugs and their side effects}

\subsection{Lopinavir/Ritonavir (Protease inhibitors)}

Lopinavir is generally co-formulated with ritonavir as a fixed-dose combination. This combination is primarily used as an antiretroviral drug and demonstrated good clinical efficacy in HIV-infected patients of all the groups (Chandwani and Shuter, 2008). Both lopinavir and ritonavir are protease inhibitors class of antiretroviral drugs and are effective against HIV-1 (Human immunodeficiency virus-1). Protease inhibitors class of drugs bind and inactivate viral proteases to stop viral replication, and thus prevent infected cells to form competent new virions. Viral proteases are specific and unique in structure for each virus. Recently, the crystal structure of the main protease of SARS-CoV-2 is elucidated which closely resembles the protease of SARS-CoV-1 (Zhang et al., 2020a). Lopinavir is three to four times more active against HIV than ritonavir. However, ritonavir, a potent inhibitor of cytochrome P450 3A4, is combined with lopinavir to increase the blood levels of lopinavir which otherwise exhibits poor bioavailability (Corbett et al., 2002; Cvetkovic and Goa, 2003). Thus, ritonavir is combined with lopinavir to increase its plasma half-life through the inhibition of cytochrome P450 enzymes. The use of lopinavir-ritonavir combination in the treatment for severe acute respiratory syndrome (SARS), along with standard treatment protocol, was associated with improved clinical outcomes (Chan et al., 2003). Despite of above research findings, the administration of lopinavir-ritonavir did not result in clinical improvement or lower mortality among COVID-19 patients (Cao et al., 2020). Even though, the lopinavir-ritonavir combination has been advocated as a treatment option against COVID-19, as the pandemic diffusion of SARS-CoV-2 is causing shortages of alternative drugs (Havlichek, 2020).

Regarding the toxicity of lopinavir-ritonavir in COVID-19 patients, gastrointestinal adverse events including anorexia, nausea, vomiting, abdominal discomfort, and diarrhea have been reported to be more common. A serious adverse effect like acute gastritis was also reported. In few COVID-19 patients, self-limiting skin eruptions were also discernible (Cao et al., 2020). Hepatotoxicity, with increased activity of aspartate aminotransferase (AST) and alanine aminotransferase (ALT), was reported with the use of both ritonavir and lopinavir in separate studies (Sulkowski et al., 2000; Nunez, 2006). Previous use of drug combination lopinavir-ritonavir is associated with the risks of cutaneous eruptions, pancreatitis, QT prolongation, and the potential for multiple drug interactions due to CYP3A inhibition. Adverse effects of lopinavir-ritonavir with very low incidences include allergic reaction, asthenia, myalgias, arthralgias, myocardial infarction, seizures, and lactic acidosis (Chandwani and Shuter, 2008). The use of protease inhibitors like lopinavir-ritonavir was also characterized by the risk of hypercholesterolemia with decreased high-density lipoprotein (HDL) cholesterol levels, increased triglyceride levels and increased low-density lipoprotein (LDL) cholesterol levels resulting in dyslipidemia. Theses occur due to disruptions of the mechanisms responsible for intracellular synthesis, storage and release of cholesterol (Nolan et al., 2005).

\subsection{Favipiravir and Remdesivir (Nucleotide analogues)}

Favipiravir was developed by Toyama Chemical Co. Ltd., Japan, in 2013 for the treatment of a broad range of influenza viruses and other RNA viruses (Furuta et al., 2013), whereas remdesivir was primarily developed by Gilead Sciences, United States, in 2017 for the treatment of Ebola virus infection (Siegel et al., 2017). Both antiviral drugs like favipiravir (a guanine analogue) and remdesivir (a C-nucleoside analogue) are prodrugs and metabolized into their active forms in the body. These drugs act on the early to intermediate stage of viral replication by inhibiting the RNA-dependent RNA polymerase. Nucleotide analogues incorporate a mimicking base into the replicating strand from which viral RNA polymerase can not elongate (Chary et al., 2020) and prevents the replication of the viral genome which result in premature termination. Favipiravir was approved as the first anti-COVID-19 drug in China, whereas, emergency use of remdesivir has been approved by the FDA for the treatment of COVID19 (Nittari et al., 2020). Member drugs of nucleoside analogue class not only suppress viral polymerase but also known to inhibit mitochondrial DNA polymerase-gamma, resulting the decreased mitochondrial DNA and synthesis of mitochondrial proteins. The mitochondrial toxicity is the basis of most of adverse effects of this class of drugs (Moyle, 2000). However, remdesivir has a relatively low affinity for human RNA polymerase II and human mitochondrial RNA polymerase and, therefore expected to have an encouraging safety profile in humans (Pardo et al., 2020). The reversible common adverse effect of remdesivir is increase in hepatic aspartic transaminase (AST) or alanine aminotransferase (ALT). As evident from controlled clinical trials, repeated doses of remdesivir were welltolerated except with a reversible increase in ALT and AST. In vitro studies indicated that increased membrane permeability and intracellular drug metabolism were probable reasons for hepatotoxicity. Interestingly, kidney was also identified as the target organ of side-effects for remdesivir in experimental animals like rats and monkeys (WHO, 2018). A need for continuous monitoring for hepatotoxicity in patients receiving remdesivir has been advocated, keeping in view the interaction between remdesivir and P-glycoprotein inhibitors (Leegwater et al., 2020). In a compassionate use cohort study on remdesivir in a small population of COVID-19 patients, the adverse effects noticed were hepatic enzymes elevation, renal impairment, maculopapular rash, and multiple-organ-dysfunction syndrome, in one or two patients (Grein et al., 2020). In a placebocontrolled randomized trial of remdesivir in the larger population of patients with severe COVID-19 infection, the most common adverse effects noted in the remdesivir treatment group were constipation, hypoalbuminaemia, hypokalaemia, anaemia, thrombocytopenia, and increased total bilirubin (Wang et al., 2020a). 
Favipiravir is generally well tolerated but known to cause transient hyperuricaemia in a dose-dependent and reversible manner without posing any clinical manifestation (Pilkington et al., 2020). In a randomized clinical trial of favipiravir with COVID-19 patients, the most common adverse effects were elevated serum uric acid level, liver enzyme abnormalities, and gastrointestinal symptoms (Chen $e t$ al., 2020). In phase II/III multicenter randomized clinical trial on patients with moderate COVID-19, adverse drug reactions to favipiravir include diarrhoea, nausea, vomiting, and an increase in hepatic transaminase levels (Ivashchenko et al., 2020). One of the serious side effects of favipiravir is teratogenicity and so, it should not be used in pregnant women (Dongyuan et al., 2020). The major safety concerns that remain associated with the use of favipiravir are hyperuricaemia, teratogenicity and QTc prolongation. Favipiravir appears to be safe and tolerable in short-term use, however, more evidence is needed to assess the long-term effects of treatment (Pilkington et al., 2020).

\subsection{Azithromycin (Macrolide antibiotic)}

Azithromycin is macrolide antibacterial drug but has been proposed as a potential therapy for the SARS-CoV-2 pneumonia (Parnham et al., 2014). Intracellular accumulation of azithromycin leads to increase in the $\mathrm{pH}$ of trans-golgi network which may alter glycosylation of human angiotensin converting enzyme 2 (hACE2) receptor and alters the binding of SARS-CoV-2 virus to respiratory cells (Nujic et al., 2012). Since, the spike protein of SARS-CoV-2 displays a ganglioside binding site and azithromycin mimic the ganglioside, it may inhibit SARS-CoV-2 infection by binding to this site (Gautret et al., 2020). In addition, azithromycin may interfere in the spike protein/CD147 interaction or CD147 expression (Poschet et al., 2020).

Azithromycin is generally well tolerated, but its relatively common adverse effects (1-5\% of patients) include gastrointestinal upset, headache and dizziness (Zuckerman et al., 2009). Moreover, hepatotoxicity after azithromycin therapy in patients with increased level of liver enzyme and other clinical symptoms were also reported (Chandrupatla et al., 2002; Das, 2011; Martinez et al., 2015). The mechanism is postulated to be hypersensitivity mediated with subsequent metabolite dependent lesions leading to ductal cholestasis. Its hepatotoxic effect is believed to be intrinsic because liver damage seems to occur in several hours to days (Lalaket al., 1993). Azithromycin weakly blocks potassium channels across the cardiac membrane which slows cardiac repolarization and QTc prolongation (Giudicessi et al., 2013). Combination of azithromycin with hydroxychloroquine may aggravate the cardiac toxicity (Hache et al., 2021). The public version of eudravigilance, the European Medicines Agency's Adverse Drug Reactions (ADR) database had reported cases of QT prolongation, arrhythmia and cardiac arrest in few patients treated with azithromycin (Sultana et al., 2020). Azithromycin should be used cautiously in patients who are also taking QT-prolonging medications like potassium channel blocker and other antiarrhythmic drugs as well as some antidepressant and antipsychotic drugs.

2.4 Chloroquine and hydroxychloroquine (Aminoquinolines)

Chloroquine and hydroxychloroquine, introduced before 1960, were used to treat malaria and chronic inflammatory diseases like rheumatoid arthritis and systemic lupus erythematosusetc, and have re-emerged as repurposed drugs to treat viral diseases, including coronavirus disease 2019 (COVID-19). Several mode of actions were reported to inhibit viral entry, uncoating, assembly and budding, viz., 'a') chloroquine inhibits the viral entry by inhibiting quinonereductase 2, which is required for the biosynthesis of sialic acid (Kwiek et al.,2004; Tortorici et al., 2019) and by interfering with the glycosylation of its cellular receptor angiotensin converting enzyme 2 receptor (ACE2) (Hofmann et al., 2020), 'b') it inhibits early stage of virus replication by inhibiting virus-endosome fusion, likely via increasing endosomal pH (Khan et al., 2010; Yang et al., 2004), c) it impairs posttranslational modifications of viral proteins through interfering with proteolytic processes and inhibition of glycosylation via specific interactions with sugar modifying enzymes or glycosyltransferases (Randolph et al., 1990), 'd') it hampers the lysosomal protein degradation and lysosomal fusion with auto phagosomes (Savarino et al., 2011; Hashem et al., 2020).

Chloroquine and hydroxychloroquine were reported to have narrow therapeutic ranges (Taylor and White, 2004). The side effects of chloroquine and hydroxychloroquine involve structural and functional changes in heart (myocardial remodeling) like an increase in cardiomyocyte size (causing hypertrophy or dilatation), alterations of the ultramicroscopic structure (e.g., loss of T-tubules) (Louch et al., 2004), modifications of the extracellular matrix, and proliferation of myofibroblasts with development of fibrosis, altered expression of ion channels (e.g., $\mathrm{K}^{+}$channels, L-type $\mathrm{Ca}^{2+}$ channels, connexins, ryanodine receptors, etc.), transporters (e.g., $\mathrm{Na}^{+}-\mathrm{Ca}^{2+}$ exchangers, sarcoplasmic reticulum ATPases, etc.) and other proteins (Mubagwa, 2020). Structural and functional alterations are manifested as conduction disturbances (bundle-branch block, incomplete or complete atrioventricular block, QT prolongation and subsequent torsade de pointes) and cardiomyopathy (hypertrophy and congestive heart failure) (Gevers et al., 2020). Further, gastrointestinal symptoms (nausea and diarrhea) and psychiatric side effects (sleeplessness, agitation, psychosis, depression, anxiety, aggressiveness and confusion) have also been reported.

In addition, chloroquine inhibits autophagy, an important homeostatic mechanism which results in myocardial ischaemia and reperfusion (Sciarretta et al., 2018). Chloroquine has also been shown to be nephrotoxic by autophagy-dependent as well as autophagy independent pathways, including interference with the cyclic adenosine monophosphate production and signaling in distal tubular cells (Wang et al., 2020b). In other preclinical studies, chloroquine inhibits autophagy and worsens ischemic cardiac injury (Ma et al., 2012) and sepsis-induced liver or lung injury (Lin et al., 2014; Zhao et al., 2019). Moreover, chloroquine may lead to endothelial dysfunction due to oxidative stress and decreased nitric oxide production secondary to lysosomal accumulation of fatty acid substrates (Gregório et al., 2021). Recently, it has been reported that the high mortality of severe COVID-19 has been related to micro or macrothrombosis, i.e., to endothelial cell injury by decreasing nitric oxide production and increasing ROS levels (Philipponnet et al., 2020). Over and above the general safety profile of chloroquine and hydroxychloroquine, adverse reactions/side effects may interfere with the clinical outcome of COVID-19 patient. Several scientific documentations associated oxidative stress with changes found in patients with COVID-19, such as its participation in the amplification and perpetuation of the cytokine storm, coagulopathy, and cell hypoxia. In this regard, the therapeutic strategy has been suggested to reduce oxidative stress using antioxidants, NF- $\mathrm{kB}$ inhibitors, Nrf2 
activators, and iron complexing agents (Cecchini et al.,2020). Thus, concurrent use of phytochemicals like piperine, quercetin/rutin and catechin may reduce the risk of adverse effect/side effect and improve patient compliance during chloroquine and hydroxychloroquine therapy.

\subsection{Tocilizumab (Humanized monoclonal antibody)}

Tocilizumab, a humanized monoclonal antibody against the interleukin-6 receptor (IL-6R), is an immunosuppressive drug, mainly used for the treatment of rheumatoid arthritis (RA) and systemic juvenile idiopathic arthritis (Rubbert-Roth et al., 2018) and recently introduced for cytokine release syndrome (to prevent cytokine storm) in the coronavirus disease 2019 (COVID-19). Tocilizumab blocks IL-6 receptors and, thereby blocking the assembling of the activated complex of IL-6 and the trans-membrane protein (gp130), which in turn stimulates regulatory B cells, and reduces the expression of inflammatory cytokines (Zhao et al., 2021). IL-6 receptor is expressed on cell surface of macrophages, neutrophils, $\mathrm{CD}^{+} \mathrm{T}$-cells, podocytes, and hepatocytes while the gp 130 is expressed ubiquitously by all the cells (Mauer et al., 2015). Interleukin (IL)-6 is one of the key inflammatory cytokines in the development of SARS induced inflammation, which raises the insufficiency of alveolar blood gas exchange and eventually leads to lung fibrosis and organ failure. IL6 promotes $\mathrm{B}$ and $\mathrm{T}$ cells differentiation, acute phase protein production and osteoclast activation; hence tocilizumab treatment thereby has been theorized to play a significant role in inducing immunomodulatory effects in COVID-19 patients (Zhou et al., 2020).

A meta-analysis study with moderate to severe rheumatoid arthritis patient was considered for efficacy and safety evaluation of tocilizumab alone and it was found that serious adverse events like infections along with mild abnormality in the lipid profile, the liver function test, and reaction at injection site were common (Chaudhry and Singh, 2020). COVID patients, who received tocilizumab were more than twice as likely to develop a superinfection as untreated controls, driven primarily by an increase in ventilator-associated pneumonia and Staphylococcus aureus accounted for approximately $50 \%$ of the bacterial pneumonias in both groups (Somers et al., 2020). In safety study of tocilizumab in COVID-19, it was observed that late-onset infections were more common on long-term followup of recipients of tocilizumab and a higher number of cases had tocilizumab-related complications like deranged liver function tests and infusion-related allergenic reactions (Pettit et al., 2020).

The class of drug, mechanism of action, side effects of drugs used in the management of COVID-19 also summarized in Table 1.

\section{Ameliorating potential of phytochemicals against side effects of COVID-19 drugs}

Phytochemicals, the non-nutritive chemical substances derived from vegetation, play a sizeable role in disease prevention. Phytochemicals which includes secondary metabolites and antioxidants have critical medicinal residences. The protective effects of these phytochemicals have been determined in many human illnesses and ailments. A wide variety of natural compounds present in food materials have been reported to have antioxidant properties. Flavonoids are the most common bioactive compounds found in medicinal vegetation (Pietta, 2000). They have shown several preventive action in various ailments due to having antimicrobial, antioxidant, anticancer and antiinflammatory effects (Cushnie and Lamb, 2005; Procházková et al.,
2011; Chirumbolo, 2012). Flavonoids, polyphenols, alkaloids, glycosides, saponins, carbohydrates and vitamins are important phytochemicals, belonging to secondary metabolites of plants. Amongst these secondary metabolites, flavonoids and polyphenols are having important role in prevention of progression of diseases state and reduction of cellular damage caused by xenobiotics such as toxicants and drugs. In this second part of review, information on mechanism of action and ameliorating potential of phytochemicals against COVID-19 drugs' side effects are critically reviewed and discussed.

\subsection{Quercetin (Flavonoid)}

Quercetin, a flavonoid found in variety of foods including apples, berries, grapes, onion, tomatoes, nuts, etc., (Li et al., 2016). Quercetin offers a variety of potential therapeutic uses primarily in the prevention and the treatment of various conditions. It inhibits production and release of histamine and other allergic substances possibly by stabilizing cell membranes of mast cells (Kempuraj et al., 2006). It inhibits cyclooxygenase, lipoxygenase (Kim et al., 1998) and reactive oxygen and nitrogen species (Knekt et al., 1997). Quercetin intake protects against coronary heart disease (CHD), caused by oxidized LDL. It was also shown to be effective inhibitor of platelets aggregation in dogs and monkeys (Osman et al., 1998). Quercetin suppresses the NLRP3 (NOD-, LRR- and pyrin domaincontaining protein 3) inflammasome by affecting these regulators. Quercetin, as an anti-inflammatory, antioxidant and analgesic inflammatory compound, probably has a potential for the treatment of severe inflammation and one of the main life-threatening conditions in patients with COVID-19 (Saeedi-Boroujeni and MahmoudianSani, 2021).

Kidney is one of the target organs for SARS-CoV-2, it is reported that many patients with SARS-CoV-2 infection would develop into acute kidney injury (AKI) (Gu et al., 2021). AKI is associated with high mortality in the clinical setting and contributes to the transition of AKI to chronic kidney disease (CKD). Interestingly, kidney was also identified as the target organ of toxicity for remdesivir, chloroquine and azithromycin (WHO, 2018; Wang et al., 2020a; Usadadia et al., 2020). Moreover, chloroquine leads to endothelial dysfunction due to oxidative stress. The quercetin has been reported to have renal protective effects which may be associated with the blockade of the activation of inflammatory, cell apoptosis-related signaling pathways. Quercetin may also act as SARS-CoV-2 inhibitor by binding with the active sites of SARS-CoV-2 main protease 3CL and ACE2, therefore cut the viral life cycle (Gu et al., 2021). A study reported that quercetin, an antioxidant flavanoid, has efficacy against chloroquininduced hepatoxicity (Mishra et al., 2013). It was able to drastically reduce the oxidative stress and hepatotoxicity resulting at higher dosages of chloroquine administration (Mishra et al., 2013). Chloroquine causes endothelial dysfunction due to oxidative stress (Gregório et al., 2021) and it has been documented that quercetin has the potential to revert back the chloroquine-induced toxicity and oxidative stress probably through scavenging the free radical generation (Mishra et al., 2013).

Quercetin has shown the hepatoprotective effects against ritonavirinduced injury to liver through alteration of oxidative stress, inflammation, apoptosis and reversing the tissue degeneration. Quercetin has been observed with attenuating effect against ritonavirinduced Bax, caspase-3, NFKB, and eNOS activation and persuaded 
the Bcl2 and pAkt level (Azmi, et al., 2020). Such promising effects favor the therapeutic potential of quercetin in hepatotoxicity and other hepatocellular diseases in COVID-19 patients. Additionally, quercetin can significantly affect the binding of viral S-protein to ACE2 receptor. ACE2 acts as the receptor for the SARS-CoV-2 virus and allows it to infect the cell. Notably, quercetin can also bind to the RBD domain of S-protein, suggesting virus neutralizing effect on SARS-CoV-2 (Pan et al., 2020). In addition to this, quercetin treatment for 4 weeks has been reported to cause marked attenuation of the azithromycin-induced biochemical alterations in serum as well as drug-induced pathological changes in liver and kidney of rats (Usadadia et al., 2020).

The use of protease inhibitors like lopinavir-ritonavir is also characterized by the risk of hypercholesterolemia which can be effectively prevented by treatment of quercetin as quercetin-treated hypercholesterolemic rats exhibited a reasonable improvement of hepatic antioxidant enzymes. Moreover, content of nitric oxide (NO) in serum and liver were markedly decreased in this model (26 and $25 \%$, respectively), and were almost normalized following quercetin administration (Mariee et al., 2012). The major side effect that remains associated with the use of favipiravir is hyperuricaemia for that quercetin may be the ideal agent to prevent kidney damage. The possible mechanism may be inhibition of liver xanthine oxidase by quercetin and improves the ability of clearing free radicals and reduces the lipid peroxidation. Thus, it may play an important role in reducing serum uric acid level and protecting the kidneys (Yao et al., 2011).

\subsection{Baicalein (Flavon)}

Baicalein is a flavone, originally isolated from the roots of Scutellaria baicalensis, Scutellaria lateriflora and Oroxylum indicum or Indian trumpet flower. Extracts of S. baicalensis and its major chemical constituents have been reported to possess antiviral, antitumor, antibacterial, antioxidant, anti-inflammatory, hepatoprotective, and neuroprotective activities (Wang et al., 2018). Several studies showed that the baicalin protects against several types of liver diseases including viral hepatitis, fatty liver disease, xenobiotic induced liver injury with a variety of pharmacological mechanisms (Yang et al., 2021). Baicalein efficiently reduces the gastrointestinal dysfunction caused by ritonavir and plays a role in reducing drug-induced adverse effects (Mehendale et al., 2007). Additionally, baicalein, potently inhibits the replication of SARS-CoV-2. Mechanistically, baicalein inhibits mitochondrial oxidative phosphorylation, and this inhibition is reversibly associated with mitochondrial permeability transition pore activity in host cells (Huang et al., 2020a). Interestingly, oral administration of crystal form $\beta$ of baicalein caused effective concentration of it against SARS-CoV-2 and it could inhibit SARSCoV-2-induced injury both in vitro and in vivo (Song et al., 2021). A study demonstrated the protective effect of baicalein on drug-induced nephrotoxicity and apoptosis by activating the antioxidant defence mechanism in kidneys and down-regulating the inflammatory response (Dai et al., 2017).

\subsection{Kaempferol (Flavonoid)}

Kaempferol or kaempherol is a secondary plant metabolite and dietary flavonoid found in many common fruits, vegetables and edible plants (e.g., kale, spinach, dill, tea, broccoli, cabbage, beans, tomato, strawberries and grapes) and in medicinal plants, (e.g., Ginkgo biloba, Moringa oleifera, etc.). Green leafy vegetables like spinach and kale, and herbs such as dill and chives are the rich plant sources of kaempferol. Alone kaempferol is an aglycone form. However, it mostly exists in their glycoside forms after bonding with glucose, rhamnose, galactose, or rutinose. Kaempfero-3-O-glucuside (astragalin) is a common natural kaempferol glycoside (CalderonMontano et al., 2011). The type of sugars bonded with aglycone form impacts their bioavailability and bioactivity (Dabeek and Marra, 2019). A wide range of pharmacological properties including antioxidant, anti-inflammatory, anticancer, cardioprotective, neuroprotective, antimicrobial, hepatoprotective, antidiabetic, antiosteoporotic, estrogenic/antiestrogenic, anxiolytic, analgesic and antiallergic activitieshas been reported for the kaempferol and its derivatives (Calderon-Montano et al., 2011; Zang et al., 2017). Kaempferol, as a potent antioxidant and anti-inflammatory agent, scavenges free radicals, decreases the formation of reactive oxygen, nitrogen species, inhibits metalloproteinase and modulates endogenous antioxidants and modulates pro-inflammatory enzyme activities (Rajendran et al., 2014; Devi et al., 2015; Silva dos Santos et al., 2021). The strong antioxidant and anti-inflammatory capability of kaempferol can be implicated in the prevention of drug-induced hepatotoxicity, cardiotoxicity and neurotoxicity. Both aglycone and glycoside forms of kaempferol are found to be hepatoprotective in action. In a research finding, kaempferol glycosides isolated from unripe soybean leaves were able to alleviate carbon tetrachlorideinducedliver injury in mice owing to its antioxidant properties (Zang et al., 2017). Since, kaempferol is also an inhibitor of p-glycoprotein and CYP3A enzyme (Piao et al., 2008); hence, it could be also used to lower the dose of antiviral anti-COVID drugs which are CYP3A substrate, and thus may reduce the risk of drug-related dose-dependent toxicities. Kaempferol can ameliorate nephrotoxicity (cisplatinmediated) by modulating oxidative stress, inflammation and apoptosis via extracellular-receptor kinases (ERK) proteins and NF$\kappa \mathrm{B}$ pathway (Wang et al., 2020b). Chloroquine causes endothelial dysfunction due to oxidative stress. The production of excessive reactive oxygen species (ROS) induces endotheliotoxicity and cardiotoxicity. Kaempferol has been documented to have protective effect on vascular endothelium against doxorubicin-induced damage by regulating 14-3-3 $\gamma$ and ADMA/DDAHaII/eNOS/NO pathway, inhibiting oxidative stress, and improving mitochondrial function (Wu et al., 2020). Such effect may also be beneficial against drugs cause cardiovascular damage in COVID patients.

In addition to ameliorative effects against toxic effects of COVID-19 drugs, kaempferol may be itself a promising anti-COVID-19 agent. Kaempferol is suggested in the top five ingredients of Chinese medicines which are promising to treat COVID-19 (Huang et al., 2020b). It is postulated that kaempferol may act by targeting on protease protein and inhibiting inflammatory mediators, regulating immunity, and eliminating free radicals. In a molecular docking study undertaken to assess bioactive compounds found in medicinal plants as potential COVID-19 main protease (Mpro) inhibitors, kaempferol has been found to have more affinity than the quercetin, luteolin-7glucoside, demethoxycurcumin, naringenin, apigenin-7-glucoside, oleuropein, curcumin, catechin, epicatechin-gallate, zingerol, gingerol, and allicin (Khaerunnisa et al., 2020). Owis et al. (2020) reported that kaempferol derivative metabolites isolated from Salvadora persica (Miswak) are the promising phytomolecules to act as COVID19 Mpro inhibitor. 


\subsection{Curcumin (Polyphenol)}

Curcumin, as an active constituent of rhizomes of Curcuma longa (turmeric), is a hydrophobic polyphenol (Akbar et al., 2018). Curcumin is used as a spice in daily food and for different purposes such as cosmetic and pharmaceutical industries (Hosseini and Hosseinzadeh, 2018). Curcumin has several pharmacological effects such as antioxidant, anti-inflammatory, anticancer, antibacterial, antiviral, and antidiabetic effects (Babaei et al., 2020).

Curcumin binds to viral $S$ protein and the viral attachment sites of the ACE2 receptor protein to inhibit the entry of SARS-CoV2 (Ho et $a l ., 2021)$. In addition, curcumin has shown to reduce inflammatory cytokines in COVID-19 patients. In a clinical study with COVID-19 patients, curcumin given as nano-curcumin at $160 \mathrm{mg} /$ day for 14 days reduced the inflammatory cytokines IL- 6 and IL- $1 \beta$ as well as clinical manifestations (fever, cough, dyspnea, headache, chest radiography, lymphocyte, white blood cells, and platelets count) in comparison to placebo-treated group (Valizadeh et al., 2020). Experimental evidences indicate that curcumin exhibits its preventive and curative effect against oxidative stress associated liver diseases through various cellular signaling pathways, viz., ERK/p38/MAPK pathway, hepatic Nrf2/ARE/Keap1 signaling, up regulation of detoxifying genes expression, TIMP signaling, AMPK pathway and lipid metabolism (Farzaei et al., 2018). Growing evidences how that curcumin can reduce chemotherapy, induced toxicity through clearing intra cellular ROS in normal tissues and modulating a series of target molecules such as adhesion molecules, infflammatory factors, transcription and growth factors, apoptosis related proteins and some enzymes and kinases, etc. (Liu et al., 2018). Looking to the pharmacological profile of curcumin, it can be used in COVID-19 patients to reduce dose of hepatotoxic antibacterial, antiviral and anti-inflammatory drugs and thereby may reducing adverse effects of allopathic drugs.

\subsection{Catechins (Polyphenols)}

Catechins are major active constituents of tea leaves and most consumed beverages (tea), second only to water, in many societies of India and abroad. Tea leaves include four major catechins (polyphenolic compound), i.e., epigallocatechin-gallate (EGCG), epigallocatechin (EGC), epicatechin-gallate (ECG) and epicatechin (EC). Catechins derived from tea demonstrate outstanding antioxidant activity due to their ability to neutralize free radicals and boost the detoxification activity of enzymes, including glutathione peroxidase, catalase and glutathione reductase (Sharangi, 2009; Miura et al., 2001). Grzesik et al. (2018) reported that catechins have greater antioxidant capacity than glutathione, vitamin $\mathrm{C}$ and flavonoids, which attests to their key role in maintaining cellular redox homeostasis. Several authors reported protective effects of catechins for liver, heart and intestine like EGCG may potentially exert a protective effect on the heart muscle in patients undergoing surgery who are susceptible to ischemic injury, by inhibiting the activation of stress-activated protein kinase and signaling pathways inducing the inflammatory response (Kim et al., 2014; Bryk et al., 2014); pre-administration of EGCG (40 $\mathrm{mg} / \mathrm{kg}$ b.w.) in fluoride intoxicated rats remarkably reversed altered parameters of cardiac tissue like DNA fragmentation, cardiac proapoptotic markers, inflammatory markers, anti-apoptotic markers, cardiac troponins, CK-MB, LDH, total cholesterol (TC), triglycerides (TG), phospholipids (PL), free fatty acids (FFA), HDL, LDL, VLDL, heart mitochondrial enzymes (ICDH, SDH, MDH, $\alpha$-KGDH, NADH dehydrogenase and $\mathrm{Ca}^{2+}$ levels), and oxidative stress markers near normalcy through its antioxidant nature (Miltonprabu and Thangapandiyan, 2015). Catechins supplementation had ameliorated the alcohol-induced liver injury by down-regulating the endotoxinmediated activation of initial signaling molecule NF- $\mathrm{kB}$ and further going downstream the signaling cascade including tumor necrosis factor-alpha, nitric oxide and reactive oxygen species and by enhancing the antioxidant profile (Bharrhan et al., 2011). Its pre-treatment showed restoration in the level of cytochrome P450 (CYP) content and in the activities of glutathione metabolizing enzymes, viz., glutathione- $S$-transferase (GST), glutathione reductase (GR) and glutathione peroxidase (GPx) and other antioxidant enzymes such as, glucose-6-phosphate dehydrogenase (G6-PD), catalase (CAT) and superoxide dismutase (SOD) in both liver and kidney when compared to tamoxifen-treated animals (Parvez et al., 2006). Following intraperitoneal administration of green tea catechins $(100 \mathrm{mg} / \mathrm{kg}$ ) for 7 or 15 days to rats fed the atherogenic diet, significantly higher mean activities of enzymatic and non-enzymatic antioxidants and lower mean levels of MDA in hepatic tissue and lower mean activities of AST, ALT, ALP and LDH in serum were observed, compared to the values in the rats fed the atherogenic diet and treated with saline (Ramesh et al., 2009). Catechin post-treatment significantly attenuated rotenone-induced imbalances in liver; pre-treatment of SD rats with catechin $(35 \mathrm{mg} / \mathrm{kg}$ b.w. for 21 days) could decrease ketoprofen induced $(50 \mathrm{mg} / \mathrm{kg}$ b.w. for 1 day) gastric mucosal oxidative damage and could prevent the reduction of GPx, GRd antioxidant enzymes, and the GSH/GSSG ratio in the intestinal mucosa (Cheng et al., 2013) and similarly, oral administration of EGCG (2 mg/kg b.w. for 3 days) could decrease indomethacin induced $(18 \mathrm{mg} / \mathrm{kg}$ b.w. for $4 \mathrm{~h}$ ) gastric mucosal oxidative damage and prevented the reduction of PG synthesis in the gastric tissues of mice (Adhikary et al., 2013). In addition, epigallocatechin-3-gallate (EGCG) promotes autophagydependent survival via influencing the balance of mTOR-AMPK pathways upon endoplasmic reticulum stress (Holczer et al., 2018) and EGCG can protect neuronal cells from or attenuate external damage through the autophagy pathway and promoting lysosomal acidification and improving the formation of autophagosomes in the liver (Zhang et al., 2020b). Collectively, catechins possess protective effect on several organs through antioxidant potency and induction of autophagy at molecular level, which can be explored to attenuate several side-effects of COVID-19 drugs.

\subsection{Gingerols (Ginger)}

Ginger (Zingiber officinale) is an important tropical medicinal herb which is being used globally as a spice and also used for healing and therapeutic proposes. Ginger belongs to the Zingiberaceae family in the order Zingiberales and class Monocotyledones (Berg, 1997). Ginger has been reported to have antioxidant, anticancer, anticoagulant, anti-inflammatory and antiemetic action in post-operative vomiting and vomiting during pregnancy. The pungent characteristics of the ginger are due to presence of gingerols and shogaols. Active constituents of ginger, viz., zingerone, gingerdiol, gingerols and shogaols have been reported to have antioxidant activities (Chrubasik et al., 2005). Ginger has shown to produce potent anti-inflammatory effects and ameliorating potential in musculoskeletal and rheumatoidarthritis conditions via inhibiting lipoxygenase and cyclooxygenase activities (Srivastava and Mustafa, 1992). Antiinflammatory potential of ginger in acute and chronic inflammation models was also reported earlier. The effect on acute and chronic inflammationis due to inhibition of macrophage activation pathway 
(Shimoda et al., 2010). Ginger had also shown to decrease serum levels of C-reactive protein (hs-CRP) and TNF- $\alpha$ in type 2 diabetic patients (Mahluji et al., 2013). Hence, ginger can be considered as a supportive herbal drug to combat the COVID-19 disease severity.

Table 1: Class, mechanism of action, side effects of drugs used in the management of COVID-19

\begin{tabular}{|c|c|c|c|c|}
\hline Name of drug & Drug-class & Mechanism of action & Side-effects/toxicities & References \\
\hline $\begin{array}{l}\text { Lopinavir } \\
\text { Ritonavir }\end{array}$ & \multirow[t]{4}{*}{ Protease inhibitors } & \multirow[t]{4}{*}{$\begin{array}{l}\text { Inactivating viral proteases } \\
\text { to stop viral replication }\end{array}$} & $\begin{array}{l}\text { Hepatotoxicity (increase } \\
\text { in AST/ ALT) }\end{array}$ & $\begin{array}{l}\text { Sulkowski et al., 2000; } \\
\text { Nunez, } 2006\end{array}$ \\
\hline \multirow[t]{3}{*}{$\begin{array}{l}\text { Lopinavir plus } \\
\text { Ritonavir }\end{array}$} & & & $\begin{array}{l}\text { G.I. events like anorexia, } \\
\text { nausea, vomiting, abdominal } \\
\text { discomfort, and diarrhea; } \\
\text { Acute gastritis }\end{array}$ & Cao et al., 2020 \\
\hline & & & $\begin{array}{l}\text { Cutaneous (skin) eruptions, } \\
\text { pancreatitis, QT prolongation, } \\
\text { CYP3A inhibition, Allergic } \\
\text { reaction, asthenia, myalgias, } \\
\text { arthralgias, myocardial } \\
\text { infarction, seizures, and lactic } \\
\text { acidosis }\end{array}$ & $\begin{array}{l}\text { Chandwani and Shuter, } \\
2008\end{array}$ \\
\hline & & & $\begin{array}{l}\text { Hypercholesterolemia, } \\
\text { Dyslipidemia }\end{array}$ & Nolan et al., 2005 \\
\hline \multirow[t]{3}{*}{ Favipiravir } & \multirow[t]{5}{*}{ Nucleotide Analogues } & \multirow[t]{5}{*}{$\begin{array}{l}\text { RNA-dependent RNA poly- } \\
\text { merase (RdRp) inhibitors }\end{array}$} & $\begin{array}{l}\text { Dose-dependent, reversible, } \\
\text { and transient hyperuricaemia, } \\
\text { QT prolongation }\end{array}$ & Pilkington et al., 2020 \\
\hline & & & $\begin{array}{l}\text { Elevated serum uric acid level, } \\
\text { Elevated hepatic enzymes, and } \\
\text { gastrointestinal symptoms } \\
\text { (diarrhoea, nausea, vomiting) }\end{array}$ & $\begin{array}{l}\text { Chen } \text { et al., } 2020 \\
\text { Ivashchenko et al., } 2020\end{array}$ \\
\hline & & & Teratogenicity & $\begin{array}{l}\text { Dongyuan et al., 2020; } \\
\text { Pilkington et al., } 2020\end{array}$ \\
\hline \multirow[t]{2}{*}{ Remdesivir } & & & $\begin{array}{l}\text { Hepatic enzymes elevation } \\
\text { Renal impairment Maculo- } \\
\text { papular rashMultiple-organ- } \\
\text { dysfunction syndrome }\end{array}$ & $\begin{array}{l}\text { WHO, 2018; } \\
\text { Grein } \text { et al., } 2020 \\
\text { Leegwater } \text { et al., } 2020 ;\end{array}$ \\
\hline & & & $\begin{array}{l}\text { Constipation, hypoal- } \\
\text { buminaemia, hypokalaemia, } \\
\text { thrombocytopenia, anaemia, } \\
\text { and increased total bilirubin }\end{array}$ & Wang et al., 2020a \\
\hline Azithromycin & Macrolide antibiotic & $\begin{array}{l}\text { Alters the binding of } \\
\text { SARS-CoV-2 virus with } \\
\text { ACE2 receptors }\end{array}$ & $\begin{array}{l}\text { Gastrointestinal upset and } \\
\text { QTc prolongation }\end{array}$ & $\begin{array}{l}\text { Zuckerman et al., 2009; } \\
\text { Nujic et al., } 2012 \\
\text { Giudicessi } \text { et al., } 2013\end{array}$ \\
\hline $\begin{array}{l}\text { Chloroquine and } \\
\text { Hydroxy- } \\
\text { chloroquine }\end{array}$ & Aminoquinolines & $\begin{array}{l}\text { Inhibits the viral entry by } \\
\text { inhibiting quinone reductase } \\
2 \text { Inhibit virus replication by } \\
\text { inhibiting virus-endosome } \\
\text { fusion }\end{array}$ & $\begin{array}{l}\text { Conduction disturbances } \\
\text { through altered expression } \\
\text { of ion channels Inhibits } \\
\text { autophagy Mycocardial } \\
\text { ischaemia and reperfusion }\end{array}$ & $\begin{array}{l}\text { Louch et al., 2004; } \\
\text { Kwiek et al., 2004; } \\
\text { Yang et al., 2004; } \\
\text { Khan et al., 2010; } \\
\text { Sciarretta et al., 2018; } \\
\text { Mubagwa, 2020; } \\
\text { Gevers } \text { et al., } 2020\end{array}$ \\
\hline Tocilizumab & $\begin{array}{l}\text { Humanized mono- } \\
\text { clonal antibody }\end{array}$ & Block IL-6 receptors & $\begin{array}{l}\text { Superinfection Mild } \\
\text { abnormality in the lipid } \\
\text { profile, the liver function } \\
\text { test }\end{array}$ & $\begin{array}{l}\text { Chaudhry and Singh, 2020; } \\
\text { Somers et al., } 2020\end{array}$ \\
\hline
\end{tabular}

Antiviral drugs are known to produce gastrointestinal side effects including nausea, vomiting and dyspepsia (Neuman et al., 2012). Occurrence of gastrointestinal intolerance is the main factor, which leads to interruption or modification of lopinavir/ritonavir therapeutic regimens (Elzi et al., 2010). Ginger showed positive effects in controlling chemotherapy-induced nausea and vomition (Mahesh et al., 2005). Ginger administration had significantly $(p<0.001)$ reduced the frequency of mild, moderate and severe nausea and vomition after antiretroviral therapy (ART) as compared to placebo control group (Dabaghzadeh et al., 2014). Anti-emetic action of ginger is mediated through 5-HT3 receptor, substance $\mathrm{P}$ and acetylcholine receptor antagonism (Marx et al., 2017). Pretreatment with ginger at 
1,000 and $2,000 \mathrm{mg} / \mathrm{kg}$ dose have been reported to reduce the nausea, tachygastria and plasma vasopressin levels in circular vection induced motion sickness (Lien et al., 2003).The COVID-19 therapeutic drugs such as remdesivir, lopinavir or ritonavir have been reported to induce hepatotoxicity (Zha et al., 2013).

Additionally, the combination of lopinavir and ritonavir in overdose can induce the endoplasmic reticulum stress pathway in the liver and lead to hepatocyte apoptosis and liver damage.In the most advanced stages of COVID-19 infection, there is an increased risk of thrombosis. The use of anticoagulants is also a well-known cause drug-induced liver damage (DILI) (Mahamid et al., 2011). The hepatoprotective effect of ginger is might be due to its antiinflammatory and antioxidant activities. Ginger had shown to produce downregulation of transforming growth factor- $\beta 1 / \mathrm{Smad} 3$, and nuclear factor-kappa $\mathrm{B}(\mathrm{NF}-\mathrm{\kappa B}) / \mathrm{I} \mathrm{KB}$ signaling pathways, which lead to decrease inflammation and oxidative stress mediated liver damage (Hasan et al., 2016).

Chemical class, chemical name pharmacological properties and ameliorative role of important phytochemicals is also abridged in Table 2. Chemical structure of each phytochemical is depicted in Figure 1.

Table 2: Chemical class, chemical name pharmacological properties and ameliorative role of important phytochemicals

\begin{tabular}{|c|c|c|c|c|}
\hline $\begin{array}{l}\text { Name and } \\
\text { chemical class }\end{array}$ & $\begin{array}{l}\text { Chemical } \\
\text { name }\end{array}$ & Sources & $\begin{array}{l}\text { Pharmacological properties } \\
\text { and ameliorative role }\end{array}$ & References \\
\hline $\begin{array}{l}\text { Quercetin } \\
\text { (Flavonoid) }\end{array}$ & $\begin{array}{l}2-(3,4- \\
\text { dihydroxyphenyl }) \\
-3,5,7- \\
\text { trihydroxychromen } \\
-4 \text {-one; dihydrate }\end{array}$ & $\begin{array}{l}\text { Apples, berries, } \\
\text { Brassica vegetables, } \\
\text { capers, grapes, onions, } \\
\text { shallots, tea, and } \\
\text { tomatoes, as well as } \\
\text { many seeds, nuts, } \\
\text { flowers, barks, and } \\
\text { leaves }\end{array}$ & $\begin{array}{l}\text { Inhibits production and release of } \\
\text { histamine, cyclooxygenase, } \\
\text { lipoxygenase, anti-inflammatory, } \\
\text { antioxidant, analgesic, renal } \\
\text { protective effects, hepatoprotective, } \\
\text { reversal of chloroquine-induced toxicity } \\
\text { and azithromycin-induced biochemical } \\
\text { alterations, inhibition of liver xanthine } \\
\text { oxidase }\end{array}$ & $\begin{array}{l}\text { Knekt et al., 1997; } \\
\text { Kempuraj et al., 2006; } \\
\text { Yao } \text { et al., 2011; } \\
\text { Mishra } \text { et al., 2013; } \\
\text { Usadadia } \text { et al., 2020; } \\
\text { Saeedi-Boroujeni and } \\
\text { Mahmoudian-Sani, 2021; } \\
\text { Gu et al., } 2021\end{array}$ \\
\hline $\begin{array}{l}\text { Baicalein } \\
\text { (Flavon) }\end{array}$ & $\begin{array}{l}\text { 5,6,7-trihydroxy-2 } \\
\text {-phenylchromen-4 } \\
\text {-one }\end{array}$ & $\begin{array}{l}\text { Roots of Scutellaria } \\
\text { baicalensis and } \\
\text { Scutellaria lateriflora, } \\
\text { Oroxylum indicum } \\
\text { (Indian trumpetflower) }\end{array}$ & $\begin{array}{l}\text { Anti-viral (inhibits the replication of } \\
\text { SARS-CoV-2), anti-tumor, anti-bacterial, } \\
\text { antioxidant, anti-inflammatory, } \\
\text { gastroprotective, hepatoprotective, } \\
\text { nehroprotective, and neuroprotective } \\
\text { activities }\end{array}$ & $\begin{array}{l}\text { Mehendale } \text { et al., 2007; } \\
\text { Dai et al., 2017; } \\
\text { Wang et al., 2018; } \\
\text { Huang } \text { et al., 2020a; } \\
\text { Yang } \text { et al., } 2021\end{array}$ \\
\hline \multirow[t]{5}{*}{$\begin{array}{l}\text { Kaempferol } \\
\text { (Flavonoid) }\end{array}$} & \multirow[t]{5}{*}{$\begin{array}{l}\text { 3,5,7-trihydroxy-2 } \\
\text {-(4-hydroxyphenyl) } \\
-4 \mathrm{H}-1 \text {-benzopyran-4 } \\
\text {-one }\end{array}$} & \multirow[t]{5}{*}{$\begin{array}{l}\text { Green leafy vegetables, } \\
\text { including spinach and } \\
\text { kale, and herbs such as } \\
\text { dill, chives, and } \\
\text { tarragon }\end{array}$} & $\begin{array}{l}\text { Potent anti-oxidant and anti-inflam- } \\
\text { matory agent }\end{array}$ & $\begin{array}{l}\text { Rajendran et al., 2014; } \\
\text { Devi et al., 2015; } \\
\text { Silva dos Santos } \\
\text { et al., } 2021\end{array}$ \\
\hline & & & $\begin{array}{l}\text { Antioxidant, anti-inflammatory, anti- } \\
\text { cancer, cardioprotective, neuroprotec- } \\
\text { tive, antimicrobial, hepatoprotective, } \\
\text { antidiabetic, anti-osteoporotic, } \\
\text { estrogenic/ antiestrogenic, anxiolytic, } \\
\text { analgesic and antiallergic activities }\end{array}$ & $\begin{array}{l}\text { Calderon-Montano et al., } \\
\text { 2011; Zang et al., } 2017\end{array}$ \\
\hline & & & $\begin{array}{l}\text { Alleviate carbon tetrachloride-induced } \\
\text { liver injury in mice model }\end{array}$ & Zang et al., 2017 \\
\hline & & & $\begin{array}{l}\text { Ameliorated Cisplatin-mediated } \\
\text { nephrotoxicity }\end{array}$ & Wang et al., 2020b \\
\hline & & & $\begin{array}{l}\text { Protective effect on vascular endot } \\
\text { helium against doxorubicin-induced } \\
\text { damage }\end{array}$ & Wu et al., 2020 \\
\hline $\begin{array}{l}\text { Curcumin } \\
\text { (Polyphenol) }\end{array}$ & $\begin{array}{l}(1 \mathrm{E}, 6 \mathrm{E})-1,7 \text {-bis } \\
\text { (4-hydroxy-3- } \\
\text { methoxyphenyl) } \\
\text { hepta-1,6-diene-3, } \\
\text { 5-dione }\end{array}$ & $\begin{array}{l}\text { Turmeric } \\
\text { (Curcuma longa) }\end{array}$ & $\begin{array}{l}\text { Antioxidant, anti-inflammatory, } \\
\text { anticancer, antibacterial, antiviral, and } \\
\text { antidiabetic effects, inhibit the entry } \\
\text { of SARS-CoV2, reduce inflammatory } \\
\text { cytokines }\end{array}$ & $\begin{array}{l}\text { Farzaei et al., 2018; } \\
\text { Babaei et al., 2020; } \\
\text { Valizadeh } \text { et al., 2020; } \\
\text { Ho et al., } 2021\end{array}$ \\
\hline
\end{tabular}




\begin{tabular}{|c|c|c|c|c|}
\hline $\begin{array}{l}\text { Catechins } \\
\text { (Polyphenols) }\end{array}$ & $\begin{array}{l}(2 \mathrm{R}, 3 \mathrm{~S})-2-(3,4- \\
\text { dihydroxyphenyl)-3, } \\
\text { 4-dihydro- } 2 \mathrm{H}- \\
\text { chromene- } 3,5,7 \\
\text {-triol }\end{array}$ & $\begin{array}{l}\text { Camellia sinensis, tea, } \\
\text { apples, persimmons, } \\
\text { cacaos, grapes, and } \\
\text { berries }\end{array}$ & $\begin{array}{l}\text { Antioxidant activity, inhibiting the } \\
\text { activation of stress-activated protein } \\
\text { kinase and signaling pathways of } \\
\text { infflammatory response, induction of } \\
\text { autophagy }\end{array}$ & $\begin{array}{l}\text { Parvez et al., 2006; } \\
\text { Sharangi, 2009; } \\
\text { Bharrhan et al., 2011; } \\
\text { Bryk et al., 2014; } \\
\text { Kim et al., 2014; } \\
\text { Zhang et al., 2020b }\end{array}$ \\
\hline $\begin{array}{l}\text { Gingerols } \\
\text { (Ginger) }\end{array}$ & $\begin{array}{l}\text { 5-hydroxy-1-(4- } \\
\text { hydroxy-3-methox- } \\
\text { yphenyl) decan-3 } \\
\text {-one }\end{array}$ & $\begin{array}{l}\text { Ginger (Zingiber } \\
\text { officinale Roscoe) }\end{array}$ & 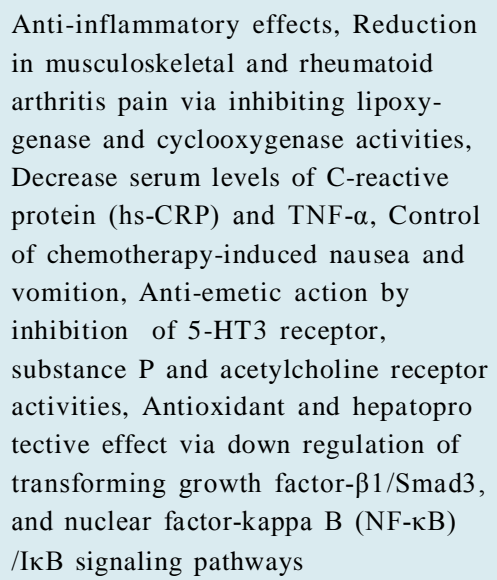 & $\begin{array}{l}\text { Srivastava and Mustafa, } \\
\text { 1992; } \\
\text { Mahesh et al., 2005; } \\
\text { Mahluji et al., 2013, } \\
\text { Hasan et al., 2016; } \\
\text { Marx et al., } 2017\end{array}$ \\
\hline
\end{tabular}<smiles>CCCCC[C@H](O)CC(=O)CCc1ccc(O)c(OC)c1</smiles>

Figure 1: Chemical structures of important phytochemicals.

\section{Conclusion}

Complications and higher level of pathogenesis may be responsible for side effects of drugs used or recommended for the management of COVID-19. Various phytochemicals like quercetin, baicalein, kaempferol, curcumin, catechins and gingerols may be useful to ameliorate the side effects of drugs. Further, research efforts are required to explore the drug-herb interaction and the ameliorating potential of such phytochemicals against COVID-19 drugs.

\section{Disclaimer}

Compilation of the information related to possible ameliorating potential of phytochemicals against side effects of commonly used drugs in COVID-19 is useful to strengthen the knowledge of scientific personnel who are working in the field of research. The information collected herewith can not be used for diagnosis and therapeutic purpose.

\section{Conflict of interest}

The authors declare that there are no conflicts of interest relevant to this article.

\section{References}

Adhikary, B.; Yadav, S. K.; Bandyopadhyay, S. K. and Chattopadhyay, S. (2011). Epigallocatechin gallate accelerates healing of indomethacininduced stomach ulcers in mice. Pharmacol. Rep., 63:527-536.

Agrawal, U.; Raju, R. and Udwadia, Z. F.(2020). Favipiravir: Anew and emerging antiviral option in COVID-19. Med. J. Armed Forces India, 76(4):370-376.

Akbar, M.U.; Rehman, K.; Zia, K. M.; Qadir, M. I.; Akash, M. S. H. and Ibrahim, M. (2018). Critical review on curcumin as a therapeutic agent: From traditional herbal medicine to an ideal therapeutic agent. Crit. Rev. Eukaryot. Gene Expr., 28(1):17-24. 
Andreani, J.; Le Bideau, M.; Duflot, I.; Jardot, P.; Rollanda, C.; Boxberger, M.; Wurtz, N.; Rolain, J.; Colson, P.; Scola, B. and Raoult, D. (2020). In vitro testing of hydroxychloroquine and azithromycin on SARS-CoV-2 shows synergistic effect. Microb. Pathog., 145:104228.

Azmi, L.; Shukla, I.; Rao, C. and Kant, P. (2020). Ritonavir induced hepatotoxicity-: 1-hydroxy-5, 7-dimethoxy-2 naphthalene-carboxaldehyde (HDNC) and quercetin protect liver via NfkB/pAkt signaling. Int. J. Infect. Dis., 101:117.

Babaei, F.; Nassiri-Asl, M. and Hosseinzadeh, H. (2020). Curcumin (a constituen of turmeric): New treatment option against COVID-19. Food. Sci. Nutr., 8(10):5215-5227.

Berg, L.R. (1997). Introductory Botany: Plants, People and the Environment. Saunders College Publication, Ft. Worth, pp:466.

Bharrhan, S.; Koul, A.; Chopra, K. and Rishi, P. (2011). Catechin suppresses an array of signaling molecules and modulates alcohol-induced endotoxin mediated liver injury in a rat model. PLoS One, 6(6): e20635.

Bryk, D.; Olejarz, W. and Zapolska-Downar, D. (2014). Mitogen-activated protein kinases in atherosclerosis. Postępy Higieny i Medycyny Doświadczalnej, 68:10-22.

Cai, M.; Bonella, F.; Dai, H.; Sarria, R.; Guzman, J. and Costabel, U. (2013) Macrolides inhibit cytokine production by alveolar macrophages in bronchiolitis obliterans organizing pneumonia. Immunobiology, 218(6):930-937.

Calderon-Montano, J. M.; Burgos-Moron, E.; Perez-Guerrero, C. and Lopez-Lazaro, M. (2011). A review on the dietary flavonoid kaempferol. Mini. Rev. Med. Chem., 11(4):298-344.

Cao, B.; Wang, Y.; Wen, D.; Liu, W.; Wang, J. J.; Fan, G; Ruan, L.; Song, B.; Cai, Y.; Wei, M.; Li, X.; Xia, J.; Chen, N.; Xiang, J.; Yu, T.; Bai, T.; Xie, X.; Zhang, L.; Li, C.; Yuan, Y.; Chen, H.; Li, H. H.; Huang, H.; Tu, S.; Gong, F.; Liu, Y.; Wei, Y.; Dong, C.; Zhou, F.; Gu, X.; Xu, J.; Liu, Z.; Zhang, Y.; Li, H. H.; Shang, L.; Wang, K.; Li, K.; Zhou, X.; Dong, X.; Qu, Z.; Lu, S.; Hu, X.; Ruan, S.; Luo, S.; Wu, J.; Peng, L.; Cheng, F.; Pan, L.; Zou, J.; Jia, C.; Wang, J. J.; Liu, X.; Wang, S.; Wu, X.; Ge, Q.; He, J.; Zhan, H.; Qiu, F.; Guo, L.; Huang, C.; Jaki, T.; Hayden, F. G.; Horby, P.W.; Zhang, D. and Wang, C. (2020). A trial of lopinavir-ritonavir in adults hospitalized with severe Covid-19. N. Engl. J. Med., 382(19):1787-1799.

Cecchini. R. and Cecchini, A. L. (2020). SARS-CoV-2 infection pathogenesis is related to oxidative stress as a response to aggression. Med. Hypotheses, 143:110102.

Chan, K. S.; Lai, S. T.; Chu, C. M.; Tsui, E.; Tam, C. Y.; Wong, M. M.; Tse, M. W.; Que, T. L.; Peiris, J. S.; Sung, J. and Wong, V. C. (2003). Treatment of severe acute respiratory syndrome with lopinavir/ritonavir: a multicentre retrospective matched cohort study. Hong Kong Med. J., 9:399406

Chandrupatla, S.; Demetris, A. J. and Rabinovitz, M. (2002). Azithromycin induced intrahepatic cholestasis. Dig. Dis. Sci., 47(10):2186-2188.

Chandwani, A. and Shuter, J. (2008). Lopinavir/ritonavir in the treatment of HIV-1 infection: a review. Ther. Clin. Risk. Manag., 4(5):10231033 .

Chary, M. A.; Barbuto, A. F.; Izadmehr, S.; Hayes, B. D. and Burns, M. M. (2020) COVID-19: therapeutics and their toxicities. J. Med. Toxicol., 16(3): 284-294.

Chaudhry, D. and Singh, P. K. (2020). Tocilizumab and COVID-19. Indian J. Crit. Care Med., 24(9):741-743.

Chen, C.; Zhang, Y.; Huang, J.; Yin, P.; Cheng, Z.; Wu, J.; Chen, S.; Zhang, Y.; Chen, B.; Lu, M.; Luo, Y.; Ju, L.; Zhang, J. and Wang, X. (2020). Favipiravir versus arbidol for COVID-19: A randomized clinical trial. Cold Spring Harbor Laboratory. Doi: 10.1101/2020.03.17.20037432.
Cheng, Y. T.; Wu, C. H.; Ho, C. Y. and Yen, G. C. (2013). Catechin protects against ketoprofen-induced oxidative damage of the gastric mucosa by upregulating Nrf2 in vitro and in vivo. J. Nutr. Biochem., 24:475-483.

Chirumbolo, S. (2012). Flavonoids in propolis acting on mast cell-mediated wound healing. Inflammopharmacology, 20:99-102.

Chrubasik, S.; Pittler, M. H. and Roufogalis, B. D. (2005). Zingiberis rhizoma: A comprehensive review on the ginger effect and efficacy profiles. Phytomedicine, 12:684-701.

Corbett, A. H.; Lim, M. L. and Kashuba, A. D. (2002). Kaletra (lopinavir/ ritonavir). Ann. Pharmacother., 36(7-8):1193-1203.

Cushnie, T. P. T. and Lamb, A. J. (2005). Antimicrobial activity of flavonoids. Int. J. Antimicrob. Agents, 26:343-356.

Cvetkovic, R. S. and Goa, K. L. (2003). Lopinavir/ritonavir: a review of its use in the management of HIV infection. Drugs, 63(8):769-802.

Dabaghzadeh, F.; Khalili, H.; Dashti-Khavidaki, S.; Abbasian, L. and Moeinifard, A. (2014). Antiretroviral -induced nausea and vomiting: a randomized clinical trial. Expert Opin. Drug Safe, 13(7):859-866.

Dabeek, W. M. and Marra, M. V. (2019). Dietary quercetin and kaempferol: Bioavailability and potential cardiovascular-related bioactivity in humans. Nutrients, 11(10):2288.

Dai, C.; Tang, S.; Wang, Y.; Velkov, T. and Xiao, X. (2017). Baicalein acts as a nephroprotectant that ameliorates colistin-induced nephrotoxicity by activating the antioxidant defence mechanism of the kidneys and down-regulating the inflammatory response. J. Antimicrob. Chemothe., 72(9):2562-2569.

Das, B.K. (2011). Azithromycin induced hepatocellular toxicity and hepatic encephalopathy in asymptomatic dilated cardiomyopathy. Indian J. Pharmacol., 43(6):736-737.

Devi, K. P.; Malar, D. S.; Nabavi, S. F.; Sureda,A.; Xiao, J.; Nabavi, S. M. and Daglia, M. (2015). Kaempferol and inflammation: from chemistry to medicine. Pharmacol. Res., 99:1-10.

Dongyuan, W.; Zigang, L. and Yihui, L. (2020). An overview of the safety, clinical application and antiviral research of the COVID-19 therapeutics. J. Infect. Public Health, 13:1405-1414.

Elzi, L.; Marzolini, C. and Furrer, H. (2010). Swiss HIV Cohort Study. Treatment modification in human immunodeficiency virus-infected individuals starting combination antiretroviral therapy between 2005 and 2008. Arch. Intern. Med., 170(1):57-65.

Farzaei, M. H.; Zobeiri, M., Parvizi, F.; El-Senduny, F. F.; Marmouzi, I.; Coy-Barrera, E.; Naseri, R.; Nabavi, S. M.; Rahimi, R. and Abdollahi, M. (2018). Curcumin in liver diseases: A systematic review of the cellular mechanisms of oxidative stress and clinical perspective. Nutrients, 10(855):1-28.

Furuta, Y.; Gowen, B. B.; Takahashi, K.; Shiraki, K.; Smee, D. F. and Barnard, D. L. (2013). Favipiravir (T-705), a novel viral RNA polymerase inhibitor. Antivir. Res., 100:446-454.

Gautret, P.; Lagier, J. C.; Parola, P., Hoang, V. T.; Meddeb, L.; Mailhe, M. Doudier, B.; Courjon, J.; Giordanengo, V.; Vieira, V. E.; Dupont, H. T.; Honoré, S.; Colson, P., Chabrière, E.; Scola, B. L.; Rolain, J.; Brouqui, P and Raoult, D. (2020). Hydroxychloroquine and azithromycin as a treatment of COVID19: Results of an open-label non-randomized clinical trial. Int. J. Antimicrob. Agents, 56(1):105949.

Gevers, S.; Kwa, M. S. G.; Wijnans, E. and van Nieuwkoop, C. (2020). Safety considerations for chloroquine and hydroxychloroquine in the treatment of COVID-19. Clin. Microbiol. Infect., 26:1276-1277.

Giudicessi, J. and Ackerman, M. (2013). Azithromycin and risk of sudden cardiac death: Guilty as charged or falsely accused? Clevel. Clin. J. Med., 80(9):539-544. 
Gregório, P.; da Cunha, R. S.; Biagini, G.; Bosquetti, B.; Budag, J.; Ortiz, A.; SánchezNiño, M. D.; Barreto, F. C. and Stinghen, A. (2021). Chloroquine may induce endothelial injury through lysosomal dysfunction and oxidative stress. Toxicol. Appl. Pharmacol., 414:115412.

Grein, J.; Ohmagari, N.; Shin, D.; Diaz, G.; Asperges, E.; Castagna, A.; Feldt, T.; Green, G.; Green, M. L.; Lescure, F. X.; Nicastri, E.; Oda, R.; Yo, K.; QuirosRoldan, E.; Studemeister, A.; Redinski, J., Ahmed, S.; Bernett, J.; Chelliah, D.; Chen, D.; Chihara, S.; Cohen, S. H.; Cunningham, J.; D'ArminioMonforte, A.; Ismail, S.; Kato, H.; Lapadula, G.; L'Her, E.; Maeno, T.; Majumder, S.; Massari, M.; Mora-Rillo, M.; Mutoh,Y.; Nguyen,D.; Verweij, E.; Zoufaly, A.; Osinusi,A. O.; DeZure, A.; Zhao, Y.; Zhong, L.; Chokkalingam, A.; Elboudwarej, E.; Telep, L.; Timbs, L.; Henne, I.; Sellers, S.; Cao, H.; Tan, S. K.; Winterbourne, L.; Desai, P.; Mera, R.; Gaggar,A.; Myers, R.P.; Brainard, D. M.; Childs, R. and Flanigan, T. (2020). Compassionate use of remdesivir for patients with severe COVID-19. N. Engl. J. Med., 382(24):2327-2336.

Grzesik, M.; Naparło, K.; Bartosz, G. and Sadowska-Bartosz, I. (2018). Antioxidant properties of catechins: comparison with other antioxidants. Food Chem., 241:480-492.

Gu, Y.Y.; Zhang, M.; Cen, H.; Wu, Y. F.; Lu, Z; Lu, F., Liu, X. S. and Lan H.Y. (2021) Quercetin as a potential treatment for COVID-19: Induced acute kidney injury: Based on network pharmacology and molecular docking study. PLoS One, 16(1):e0245209.

Hache, G.; Rolain, J. M.; Gautret, P.; Deharo, J. C.; Brouqui, P.; Raoult, D. and Honore, S. (2021). Combination of hydroxychloroquine plus azithromycin as potential treatment for COVID-19 patients: Safety profile, drug Interactions, and management of toxicity. Microb. Drug Resist., 27(3):281-290.

Hasan, I. H.; El-Desouky, M. A.; Hozayen, W. G. and Abd el Aziz, G. M. (2016). Protective effect of Zingiber officinale against $\mathrm{CCl}$-induced liver fibrosis is mediated through down regulating the TGF- $\beta 1 / \mathrm{smad} 3$ and NF-kb/ikb pathways. Pharmacology, 97:1-9.

Hashem, A. M.; Alghamdi, B. S.; Algaissi,A. A.; Alshehri, F. S.; Bukhari, A.; Alfaleh, M. A. and Memish, Z. A. (2020). Therapeutic use of chloroquine and hydroxychloroquine in COVID-19 and other viral infections: A narrative review. Travel Med. Infect. Dis., 35:101735.

Havlichek, Jr. D. (2020). A Trial of Lopinavir-Ritonavir in Covid-19. N. Engl. J. Med., 382(21):e68.

Ho, P.; Zheng, J. Q.; Wu, C. C.; Hou, Y. C.; Liu, W. C.; Lu, C. L.; Zheng, C. M.; Lu, K. C. and Chao, Y. C. (2021). Perspective adjunctive therapies for COVID19: Beyond antiviral therapy. Int. J. Med. Sci., 18(2):314-324.

Hofmann, M.; Kleine-Weber, H.; Schroeder, S.; Kruger, N.; Herrler, T.; Erichsen, S.; Schiergens, T. S.; Herrler, G.; Wu, N. H.; Nitsche, A.; Müller, M. A.; Drosten, C. and Pöhlmann S. (2020). SARS-CoV-2 cell entry depends on ACE2 and TMPRSS2 and is blocked by a clinically proven protease inhibitor. Cell, 181:271-80

Holczer, M.; Besze, B.; Zámbó, V.; Csala, M.; Bánhegyi, G. and Kapuy, O. (2018). Epigallocatechin-3-Gallate (EGCG) promotes autophagy-dependent survival via influencing the balance of mTOR-AMPK pathways upon endoplasmic reticulum stress. Oxid. Med. Cell. Longev., 18: $1-15$.

Hosseini, A. and Hosseinzadeh, H. (2018). Antidotal or protective effects of Curcuma longa (turmeric) and its active ingredient, curcumin, against natural and chemical toxicities: A review. Biomed. Pharmacother., 99:411-421.

Huang, S.; Liu, Y.; Zhang, Y.; Zhang, Y.; Zhang, R.; Zhu, C.; Fan, L.; Pei, G.; Zhang, B. and Shi, Y. (2020a). Baicalein inhibits SARS-CoV-2/VSV replication with interfering mitochondrial oxidative phosphorylation in a mPTP dependent manner. Sig. Transduct. Target. Ther., 5(1):doi:10. 1038/s4 1392-020-00353-x.

Huang, Y. F.; Bai, C.; He, F.; Xie, Y. and Zhou, H. (2020b). Review on the potential action mechanisms of chinese medicines in treating coronavirus disease 2019 (COVID-19). Pharmacol. Res., 158:104939.
Ivashchenko, A. A.; Dmitriev, K. A.; Vostokova, N. V; Azarova, V. N.; Blinow, A. A.; Egorova,A. N.; Gordeev, I. G.; Ilin, A. P.; Karapetian, R. N.; Kravchenko, D. V.; Lomakin, N. V.; Merkulova, E. A.; Papazova, N. A.; Pavlikova, E. P.; Savchuk, N. P.; Simakina, E. N.; Sitdekov, T. A.; Smolyarchuk, E. A.; Tikhomolova, E. G.; Yakubova, E. V. and Ivachtchenko, A.V. (2020). AVIFAVIR for treatment of patients with moderate COVID-19: Interim results of a phase II/III multicenter randomized clinical trial. Clin. Infect. Dis., doi: 10.1101/ 2020.07.26.20154724.

Kempuraj, D.; Castellani, M. L. and Petrarca, C. (2006). Inhibitory effect of quercetin on tryptase and interleukin- 6 release, and histidine decarboxylase mRNA transcription by human mast cell-1 cell line. Clin. Exp. Med., 6(4):150-156

Khaerunnisa, S.; Kurniawan, H.; Awaluddin, R.; Suhartati, S. and Soetjipto, S. (2020). Potential inhibitor of COVID-19 main protease (Mpro) from several medicinal plant compounds by molecular docking study. doi: 10.20944/preprints202003.0226.v1.

Khan, M.; Santhosh, S. R.; Tiwari, M.; Lakshmana Rao, P. V. and Parida, M. (2010). Assessmen of in-vitro prophylactic and therapeutic efficacy of chloroquine against Chikungunya virus in vero cells. J. Med. Virol., 82:817-24.

Kim, H. P.; Mani, I. and Iversen, L. (1998). Effects of naturally-occurring flavonoids and bioflavonoids on epidermal cyclooxygenase and lipoxygenase from guinea-pigs. Prostaglandins Leukot. Essent. Fatty Acids, 58:17-24

Kim, S. J.; Li, M.; Jeong, C. W.; Bae, H. B.; Kwak, S. H.; Lee, S. H.; Lee, H. J.; Heo, B. H.; Yook, K. B.; Yoo, K. Y. (2014). Epigallocatechin-3-Gallate, a Green Tea Catechin, Protects the Heart against Regional IschemiaReperfusion Injuries through Activation of RISK Survival Pathways in Rats. Arch. Pharm. Res., 37:1079-1085.

Knekt, P.; Jarvinen, R. and Seppanen, R. (1997). Dietary flavonoids and the risk of lung cancer and other malignant neoplasms. Am. J. Epidemiol., 146:223-30.

Kwiek, J. J.; Haystead, T. A. and Rudolph, J. (2004). Kinetic mechanism of quinoneoxidoreductase 2 and its inhibition by the antimalarial quinolines. Biochemistry, 43:4538-47.

Lalak, N. J. and Morris, D. L. (1993). Azithromycin clinical pharmacokinetics. Clin. Pharmacokinet., 25:370-374.

Leegwater, E.; Strik, A.; Wilms, E. B.; Bosma, L. B. E.; Burger, D. M.; Ottens, T. H. and van Nieuwkoop, C. (2020). Drug-induced liver injury in a patient with coronavirus disease 2019: potential interaction of remdesivir with p-glycoprotein inhibitors. Clin. Infect. Dis., doi: 10.1093/cid/ ciaa 883 .

Li, C.; Zu, S.; Deng, Y.Q.; Li, D.; Parvatiyar, K.; Quanquin, N.; Shang, J.; Sun, N.; Su, J.; Liu, Z; Wang, M.; Aliyari, S. R.; Li, X.; Wu, A.; Ma, F.; Shi, Y.; Saines, K.N.; Jung, J. U.; Qin, F. X.; Qin, C. F.; Cheng, G. (2019). Azithromycin protects against Zika virus infection by upregulating virus-induced typeI and III interferon responses. Antimicrob. Agents Chemother., 63(12): doi: 10.1128/aac.00394-19.

Li, Y.; Yao, J.; Han, C.; Yang, J.; Chaudhry, M.T.; Wang, S.; Liu, H. and Yin, Y. (2016). Quercetin, Inflammation and immunity. Nutrients, 8(3):167.

Lien, H. C.; Sun, W. M.; Chen, Y.H.; Kim, H.; Hasler, W. and Owyang, C. (2003). Effects of ginger on motion sickness and gastric slow-wave dysrhythmias induced by circular vection. Am. J. Physiol. Gastrointest. Liver Physiol., 284:G481-G489.

Lin, C.W.; Lo, S. and Perng D.S. (2014). Complete activation of the autophagic process attenuates liver injury and improves survival in septic mice. Shock, 41:241-249.

Liu, Z.; Huang, P.; Law, S.; Tian, H.; Leung, W. and Xu, C. (2018). Preventive effect of curcumin against chemotherapy induced side effects. Front Pharmacol., 9:1374. 
Louch, W. (2004). Reduced synchrony of $\mathrm{Ca} 2+$ release with loss of $\mathrm{T}$ tubules: A comparison to $\mathrm{Ca} 2+$ release in human failing cardiomyocytes. Cardiovasc. Res., 62:63-73.

Ma X.; Liu H. and Foyil S.R. (2012). Impaired autophagosome clearance contributes to cardiomyocyte death in ischemia/reperfusion injury. Circulation, 125:3170-3181

Mahamid, M.; Mader, R. and Safadi, R. (2011). Hepatotoxicity of tocilizumab and anakinra in rheumatoid arthritis: Management decisions. Clin. Pharmacol., 3:39-43.

Mahesh, R.; Venkatesha Perumal, R. and Pandi, P. (2005). Cancer chemotherapyinduced nausea and vomiting: Role of mediators, development of drugs and treatment methods. Pharmazie, 60(2):83-96.

Mahluji, S.; Ostadrahimi, A.; Mobasseri, M.; Attari, V.E. and Payahoo, L. (2013). Anti-inflammatory effects of Zingiber officinale in type 2 diabetic patients. Adv. Pharmaceut. Bull., 3 (2): 273-276.

Mariee, A. D. Abd-Allah G.M. and El-Beshbishy H. A. (2012). Protective effect of dietary flavonoid quercetin against lipemic-oxidative hepatic injury in hypercholesterolemic rats. Pharm. Biol., 50(8): 10191025 .

Martinez, M. A.; Vuppalanchi, R.; Fontana, R. J.; Stolz, A.; Kleiner, D. E.; Hayashi, P. H.; Gu, J., Hoofnagle, J. H. and Chalasani, N. (2015). Clinical and histologic features of azithromycin-induced liver injury. Clin. Gastroenterol. Hepatol., 13(2):369-376.

Marx, W.; Ried, K. and McCarthy, A. L. (2017). Ginger-mechanism of action in chemotherapy-induced nausea and vomiting: a review. Crit. Rev. Food Sci. Nutr., 57:141-146.

Mauer, J.; Denson, J. L. and Bruning, J. C. (2015). Versatile functions for IL-6 in metabolism and cancer. Trends Immunol., 36: 92-101.

Mehendale, S.; Aung, H.; Wang, C. Z.; Tong, R.; Foo, A.; Xie, J. T. and Yuan, C.S (2007). Scutellaria baicalensis and a constituent flavonoid, baicalein, attenuate ritonavir-induced gastrointestinal side-effects. J. Pharm. Pharmacol., 59(11):1567-1572.

Menzel, M.; Akbarshahi, H.; Bjermer, L. and Uller, L. (2016). Azithromycin induces antiviral effects in cultured bronchial epithelial cells from COPD patients. Sci. Rep., 6:28698.

Miltonprabu, S. and Thangapandiyanm, S. (2015). Epigallocatechin gallate potentially attenuates Fluoride induced oxidative stress mediated cardiotoxicity and dyslipidemia in rats. J. Trace Elem. Med. Biol., 29: 321-335.

Mishra, S. K.; Singh, P. and Rath, S. K. (2013). Protective effect of quercetin on chloroquine-induced oxidative stress and hepatotoxicity in mice. Malar. Res. Treat., 2013:1-10.

Miura, Y.; Chiba, T.; Tomita, I.; Koizumi, H.; Miura, S.; Umegaki, K.; Hara, Y. and Ikeda, M. (2001). Tea catechins prevent the development of atherosclerosis in apoprotein e-deficient mice. J. Nutr., 131:27-32.

Moyle, G. (2000). Clinical manifestations and management of antiretroviral nucleoside analog-related mitochondrial toxicity. Clin. Therap., 22(8): 911-936.

Mubagwa, K. (2020). Cardiac effects and toxicity of chloroquine: a short update. Int. J. Antimicrob. Agents, 56(2):106057.

Neuman, M. G.; Schneider, M.; Nanau, R. M. and Parry, C. (2012). HIVantiretroviral therapy induced liver, gastrointestinal, and pancreatic injury. Int. J. Hepatol., 2012:760706.

Nittari, G.; Pallotta, G.; Amenta, F. and Tayebati, S. K. (2020). Current pharmacological treatments for SARS-COV-2: A narrative review. Eur. J. Pharmacol., 882:173328.
Nolan, D.; Reiss, P. and Mallal, S. (2005). Adverse effects of antiretroviral therapy for HIV infection: a review of selected topics. Expert Opin. Drug Saf, 4:201-218.

Nugraha, R. V.; Ridwansyah, H.; Ghozali, M.; Khairani, A. F. and Atik, N. (2020). Traditional herbal medicine candidates as complementary treatments for covid-19: A review of their mechanisms, pros and cons. Evid Based Complement. Alternat. Med., 20:1-12.

Nujic, K.; Banjanac, M.; Munic, V.; Polancec, D. and Haber, V. E. (2012). Impairment of lysosomal functions by azithromycin and chloroquine contributes to anti-inflammatory phenotype. Cell. Immunol., 279(1):78-86.

Nunez, M. (2006). Hepatotoxicity of antiretrovirals: incidence, mechanisms and management. J. Hepatol., 44:132-139.

Osman, H. E.; Maalej, N. and Shanmuganayagam, D. (1998). Grape juice but not orange or grapefruit juice inhibits platelet activity in dogs and monkeys. J. Nutr., 128:2307-2312.

Owis, A. I.; El-Hawary, M. S.; El Amir, D.; Aly, O. M.; Abdelmohsen, U. R. and Kamel, M. S. (2020). Molecular docking reveals the potential of Salvadora persica flavonoids to inhibit COVID-19 virus main protease. RSC Adv., 10(33):19570-19575.

Pan, B.; Fang, S.; Zhang, J.; Pan, Y.; Liu, H.; Wang, Y.; Li, M. and Liu, L. (2020). Chinese herbal compounds against SARS-CoV-2: Puerarin and quercetin impair the binding of viral S-protein to ACE2 receptor. Comput. Struct. Biotechnol. J., 18:3518-3527.

Pardo, J.; Shukla, A. M.; Chamarthi. G. and Gupte, A. (2020). The journey of remdesivir: from Ebola to COVID-19. Drugs Context, 9:4-14.

Parnham, M. J.; Haber, V. E.; Bourboulis, E. J. G.; Perletti, G;; Verleden, G. M. and Vos, R. (2014).Azithromycin: mechanisms of action and their relevance for clinical applications. Pharmacol. Ther., 143(2):225245 .

Parvez, S.; Tabassum, H.; Rehman, H.; Banerjee, B. D.; Athar, M. and Raisuddin, S. (2006). Catechin prevents tamoxifen-induced oxidative stress and biochemical perturbations in mice. Toxicol., 225(2-3):109-118.

Pettit, N. N.; Nguyen C.T.; Mutlu G. M.; Wu D.; Kimmig L. and Pitrak D. and Pursell, K. (2020). Late onset infectious complications and safety of tocilizumab in the management of COVID-19. J. Med. Virol. 93: 1459-1464.

Philipponnet, C.; Aniort, J.; Chabrot, P.; Souweine, B. and Heng, E. (2020).Renal artery thrombosis induced by COVID-19.Clin. Kidney J., 13: 713-713.

Piao, Y.; Shin, S. C. and Choi, J. S. (2008). Effects of oral kaempferol on the pharmacokinetics of tamoxifen and one of its metabolites, 4 hydroxytamoxifen, after oral administration of tamoxifen to rats. Biopharm. Drug Dispos., 29(4):245-249.

Pietta, P. G. (2000). Flavonoids as antioxidants. J. Nat. Prod., 63:10351042 .

Pilkington, V.; Pepperrell, T. and Hill, A. (2020). A review of the safety of favipiravir: A potential treatment in the COVID-19 pandemic?. J. Virus Erad., 6(2):45-51.

Poschet, J. F.; Perkett, E. A.; Timmins, G. S. and Deretic, V. (2020). Azithromycin and ciprofloxacin have a chloroquine-like effect on respiratory epithelial cells. doi:10.1101/2020.03.29.008631.

Procházková, D.; Boušová, I. and Wilhelmová, N. (2011). Antioxidant and prooxidant properties of flavonoids. Fitoterapia, 82:513-523.

Rajendran, P.; Rengarajan, T.; Nandakumar, N.; Palaniswami, R.; Nishigaki, Y. and Nishigaki, I. (2014). Kaempferol, a potential cytostatic and cure for inflammatory disorders. Eur. J. Med. Chem., 86:103-112. 
Ramesh, E.; Jayakumar, T.; Elanchezhian, R.; Sakthivel, M.; Geraldine, P.; Thomas, P. A. (2009). Green tea catechins, alleviate hepatic lipidemic-oxidative injury in Wistar rats fed an atherogenic diet. Chem. Biol. Interact., 180(1): $10-19$.

Randolph, V. B.; Winkler, G. and Stollar, V. (1990). Acidotropic amines inhibit proteolytic processing of flavivirusprM protein. Virology, 174:450458 .

Rubbert-Roth, A.; Furst, D. E.; Nebesky, J. M.; Jin, A. and Berber, E. (2018). A review of recent advances using tocilizumab in the treatment of rheumatic diseases. Rheumatol. Ther., 5:21-42.

Saeedi-Boroujeni, A. and Mahmoudian-Sani, M. R. (2021). Anti-inflammatory potential of Quercetin in COVID-19 treatment. J. Inflamm., 18(1). doi:10.1186/s12950-021-00268-6.

Savarino, A. (2011). Use of chloroquine in viral diseases. Lancet Infect. Dis., 11:653-654.

Schögler, A.; Kopf, B. S.; Edwards, M. R.; Johnston, S. L.; Casaulta, C. and Kieninge E. (2015). Novel antiviral properties of azithromycin in cystic fibrosis airway epithelial cells. Eur. Respir. J., 45:428-39.

Sciarretta, S.; Maejima, Y.; Zablocki, D. and Sadoshima, J. (2018). The role of autophagy in the heart. Annu. Rev. Physiol., 80:1-26.

Sharangi, A. B. (2009). Medicinal and Therapeutic Potentialities of Tea (Camellia Sinensis L.) -A Review. Food Res. Int., 42:529-535.

Shimoda, H.; Shan, S. J.; Tanaka, J.; Seki, A.; Seo, J. W.; Kasajima, N.; Tamura, S.; Ke, Y. and Murakami, N. (2010). Anti-inflammatory properties of red ginger (Zingiber officinale var. Rubra) extract and suppression of nitric oxide production by its constituents. J. Med. Food, 13(1):156162

Siegel, D.; Hui, H. C.; Doerffler, E.; Clarke, M. O.; Chun, K.;Zhang, L.; Neville, S.; Carra, E.; Lew, W.; Ross, B. and Wang, Q. (2017). Discovery and synthesis of a phosphoramidateprodrug of a pyrrolo [2, 1-f][triazin-4-amino] adenine C-nucleoside (GS-5734) for the treatment of Ebola and emerging viruses. J. Med. Chem., 60:1648-1661.

Silva dos Santos, J.; Gonçalves Cirino, J. P.; de Oliveira Carvalho, P. and Ortega, M. M. (2021). The Pharmacological action of kaempferol in central nervous system diseases: A review. Front. Pharmacol., 11:565-700.

Silva, J. C.; Mariz, H.A.; Rocha, L. F.; Jr. Oliveira, P.S.; Dantas, A. T. and Duarte, A. L. (2013). Hydroxychloroquine decreases Th17-related cytokines in systemic lupus erythematosus and rheumatoid arthritis patients. Clinics (Sao Paulo),, 68:766-771.

Somers, E. C.; Eschenauer, G. A.; Troost, J. P.; Golob, J. L.; Gandhi, T. N.; Wang, L. and Zhou, N., (2020). Tocilizumab for treatment of mechanically ventilated patients with COVID-19. Clin. Infec. Dis., Cold Spring Harbor Laboratory; doi.org/10.1101/2020.05.29.20117358.

Song, J.; Zhang, L.; Xu, Y.; Yang, D.; Zhang, L.; Yang, S.; Zhang W;Wang, J.; Tian, S.;Yang S.; Yuan, T.; Liu,A.; Lv, Q.; Li, F.; Liu, H.; Hou, B.; Peng, X.; Lu, Y. and Du, G. (2021). The comprehensive study on the therapeutic effects of baicalein for the treatment of COVID-19 in vivo and in vitro. Biochem. Pharmacol., 183:114302.

Srivastava, K. C. and Mustafa, T. (1992). Ginger (Zingiber officinale) in rheumatism and musculoskeletal disorders. Med. Hypotheses, 39 (4):342-348.

Sulkowski, M. S.; Thomas, D. L.; Chaisson, R. E. and Moore, R. D. (2000). Hepatotoxicity associated with antiretroviral therapy in adults infected with human immunodeficiency virus and the role of hepatitis C or B virus infection. J. am. Med. Assoc., 283:74-80.

Sultana, J.; Cutroneo, P. M.; Crisafulli, S.; Puglisi, G.; Caramori, G. and Trifiro, G (2020). Azithromycin in COVID-19 Patients: Pharmacological Mechanism, Clinical Evidence and Prescribing Guidelines. Drug Safe, 21:1-8.
Taylor, W. R. and White, N. J. (2004). Antimalarial drug toxicity: A review. Drug Safe, 27:25-61.

Tortorici, M. A.; Walls, A. C.; Lang, Y.; Wang, C.; Li, Z. and Koerhuis, D. (2019). Structural basis for human corona virus attachment to sialic acid receptors. Nat. Struct. Mol. Biol., 26:481-489.

U. N. (2020). Impact of the COVID-19: Pandemic on trade and development: transitioning to a new normal. United Nations Publications.

Usadadia, S. V.; Patel, J. M.; Vihol, P. D. and Urkude, A. P. (2020). Protective effect of quercetin on azithromycin induced hepatotoxicity and nephrotoxicityinwistar rats. Int .J. Curr. Microbiol. App. Sci., 9(9): 2926-2934.

Valizadeh, H.; Abdolmohammadi-Vahid, S.; Danshina, S.; Ziya, G. M.; Ammari, A.; Sadeghi, A.; Roshangar, L.; Aslani, S.; Esmaeilzadeh, A.; Ghaebi, M.; Valizadeh, S. and Ahmadi, M. (2020). Nano-curcumin therapy, a promising method in modulating inflammatory cytokines in COVID-19 patients. Int. Immunopharmacol., 89(Pt B): 107088.

W. H. O. (2018). WHO R \& D Blueprint - Ad-Hoc expert consultation on clinical trials for Ebola therapeutics. World Health Organization. Published 11 October, 2018.

W. H. O. (2020). Timeline - COVID-19. (n.d.). Retrieved May 29, 2020, from https://www.who.int/news-room/detail/27-04-2020-whotimeline-COVID-19.

Wang, Y.; Zhang, D.; Du, G.; Du, R.; Zhao, J.; Jin, Y.; Fu, S.; Gao, L.; Cheng, Z; Lu, Q.; Hu, Y.; Luo, G.; Wang, K.; Lu, Y.; Li, H.; Wang, S.; Ruan, S.; Yang, C.; Mei, C.; Wang, Y.; Ding, D.; Wu, F.; Tang, X.; Ye, X.; Ye, Y.; Liu, B.; Yang, J.; Yin, W.; Wang; A., Fan, G.; Zhou, F.; Liu, Z; Gu, X.; Xu, J.; Shang, L.; Zhang, Y.; Cao, L.; Guo, T.; Wan, Y.; Qin, H.; Jiang, Y.; Jaki, T.; Hayden, F. G.; Horby, P. W.; Cao, B. and Wang, C. (2020a). Remdesivir in adults with severe COVID-19: A randomized, double-blind, placebo-controlled, multicentre trial. Lancet, 395(10236):1569-1578.

Wang, Z. L.; Wang, S.; Kuang, Y.; Hu, Z. M.; Qiao, X. and Ye, M. (2018). A comprehensive review on phytochemistry, pharmacology, and flavonoid biosynthesis of Scutellaria baicalensis. Pharma. Biol., 56(1):465-484

Wang, Z; Sun, W.; Sun, X.; Wang,Y. and Zhou M. (2020b). Kaempferol ameliorates Cisplatin induced nephrotoxicity by modulating oxidative stress, inflammation and apoptosis via ERK and NF- $\kappa$ B pathways. AMB Expr., 10(1). doi: 10.1186/s13568-020-00993-w.

Wu, W.; Yang, B.; Qiao, Y.; Zhou, Q.; He, H. and He, M. (2020). Kaempferol protects mitochondria and alleviates damages against endotheliotoxicity induced by doxorubicin. Biomed. Pharmacother., 126: 110040 .

Yang, J.; Li, M.; Zhang, C. and Liu, D. (2021). Pharmacological properties of baicalin on liver diseases: A narrative review. Pharmacol. Rep., Springer Science and Business Media LLC; http://dx.doi.org/ 10.1007/s43440-021-00227-1.

Yang, Z Y.; Huang, Y.; Ganesh, L.; Leung, K.; Kong, W. P. and Schwartz, O. (2004).pHdependent entry of severe acute respiratory syndrome corona virus is mediated by the spike glycoprotein and enhanced by dendritic cell transfer through DC-sign. J. Virol., 78:5642-50.

Yao, F.; Zhang, R.; Fu, R. and He, W. (2011). Preventive and therapeutic effects of quercetin on hyperuricemia and renal injury in rats. Wei Sheng Yan Jiu., 40(2):175-177. PMID: 21560303.

Zang, Y.; Zhang, D.; Yu, C.; Jin, C. and Igarashi, K. (2017). Antioxidant and hepatoprotective activity of kaempferol 3-O- $\beta$-D- $(2,6-d i-O-\alpha-$ L-rhamnopyranosyl) galactopyronoside against carbon tetrachloride-induced liver injury in mice. Food Sci. Biotechnol., 26(4): 1071-1076. 
Zarogoulidis, P.; Papanas, N.; Kioumis, I.; Chatzaki, E.; Maltezos, E. and Zarogoulidis, K. (2012). Macrolides: from in vitro anti-inflammatory and immunomodulatory properties to clinical practice in respiratory diseases. Eur. J. Clin. Pharmacol., 68:479-503.

Zha, B. S.; Wan, X. and Zhang, X. (2013). HIV protease inhibitors disrupt lipid metabolism by activating endoplasmic reticulum stress and inhibiting autophagy activity in adipocytes. PLoS One, 8(3):e5951444.

Zhang, L.; Lin, D.; Sun, X.; Curth, U.; Drosten, C.; Sauerhering, L.; Becker, S.; Rox K. and Hilgenfeld, R. (2020a). Crystal structure of SARS-CoV-2 main protease provides a basis for design of improved $\alpha$-ketoamide inhibitors. Science, 368(6489):409-412.

Zhang, S., Cao, M. and Fang, F. (2020b). The Role of epigallocatechin-3gallate in autophagy and endoplasmic reticulum stress (ERS)-induced apoptosis of human diseases. Med. Sci. Monit., 26:e924558.
Zhao, H.; Chen, H. and Xiaoyin M. (2019). Autophagy activation improves lung injury and inflammation. Inflammation, 42:426-439.

Zhao, M.; Lu, J.; Tang, Y.; Dai, Y.; Zhou, J. and Wu, Y. (2021). Tocilizumab for treating COVID-19: a systemic review and meta-analysis of retrospective studies. Eur. J. Clin. Pharmacol., 77: 311-319.

Zhou, Y.; Fu, B.; Zheng, X.; Wang, D.; Zhao, C.; Qi., Y.; Sun, R.; Tian, Z. and Xu, Z. (2020). Aberrant pathogenic $\mathrm{GM} \mathrm{CSF}^{+} \mathrm{T}$ cells and inflammatory $\mathrm{CD}^{14+} \mathrm{CD}^{16+}$ monocytes in severe pulmonary syndrome patients of a new coronavirus. Cold Spring Harbor Laboratory; doi.org/10.1101/ 2020.02 .12 .945576 .

Zuckerman, J. M.; Qamar, F. and Bono, B. R. (2009). Macrolides, ketolides, and glycylcyclines: azithromycin, clarithromycin, telithromycin, tigecycline. Infect. Dis. Clin. North. Am., 23(4):997-1026. 